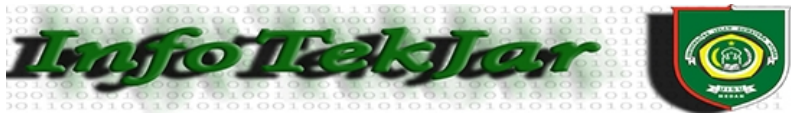

\title{
SIMULASI INTERKONEKSI ANTARA AUTONOMOUS SYSTEM (AS) MENGGUNAKAN BORDER GATEWAY PROTOCOL (BGP)
}

\author{
Hari Antoni Musril \\ Jurusan Pendidikan Teknik Informatika dan Komputer, FTIK, Institut Agama Islam Negeri (IAIN) Bukittinggi \\ Gurun Aur Kubang Putih, Kampus II IAIN Bukittinggi, Kab. Agam (26181), Sumatera Barat, Indonesia \\ kumayik@yahoo.co.id
}

\begin{abstract}
An autonomous system (AS) is the collection of networks having the same set of routing policies. Each AS has administrative control to its own inter-domain routing policy. Computer networks consisting of a bunch of AS's with different routing will not be able to interconnecttion one another. This is causes communication in the network to be inhibited. For that we need a protocol that can connect each different AS. Border Gateway Protocol (BGP) is an inter-domain routing protocol i.e. between different AS that is used to exchange routing information between them. In a typical inter-network (and in the Internet) each autonomous system designates one or more routers that run BGP software. BGP routers in each AS are linked to those in one or more other AS. The ability to exchange table routing information between Autonomous System (AS) is one of the advantages BGP. BGP implements routing policies based a set of attributes accompanying each route used to pick the "shortest" path across multiple ASs, along with one or more routing policies. BGP uses an algorithm which cannot be classified as a pure "Distance Vector", or pure "Link State". It is a path vector routing protocol as it defines a route as a collection of a number of AS that is passes through from source AS to destination AS. This paper discusses the implementation of the BGP routing protocol in the network that have different AS in order to interconnect. Its application using Packet Tracer 7.0 software for prototyping and simulating network. So that later can be applied to the actual network. Based on experiments that have been carried out, the BGP routing protocol can connect two routers that have different autonomous system.
\end{abstract}

\begin{abstract}
Abstrak-Autonomous systems (AS) adalah kumpulan jaringan yang memiliki seperangkat kebijakan routing yang sama. Setiap AS memiliki kewenangan administratif sendiri untuk mengatur policy routing interdomain. Jaringan komputer yang terdiri dari sekumpulan AS dengan routing yang berbeda-beda tidak akan dapat melakukan interkoneksi antara satu dengan yang lainnya. Hal ini menyebabkan komunikasi dalam jaringan menjadi terhambat. Untuk itu dibutuhkan protokol yang bisa menghubungkan setiap AS yang berbeda tersebut. Border Gateway Protocol (BGP) adalah protokol perutean antara AS yang berbeda yang digunakan untuk menukar informasi routing di antara keduanya. Dalam sebuah jaringan autonomous systems menunjuk satu atau lebih router yang menjalankan perangkat lunak BGP. Router BGP pada setiap AS terhubung ke satu atau lebih AS lainnya. Kemampuan untuk saling bertukar informasi tabel routing antar AS merupakan salah satu keunggulan dari BGP. BGP menerapkan kebijakan perutean berdasarkan sekumpulan atribut yang menyertai setiap rute yang digunakan untuk memilih jalur "terpendek" di beberapa AS, bersamaan dengan satu atau beberapa kebijakan perutean. BGP menggunakan algoritma yang tidak dapat diklasifikasikan sebagai "Distance Vector" murni, atau "Link State" murni. BGP adalah protokol path vector routing karena mendefinisikan rute sebagai kumpulan sejumlah AS yang lewat dari AS sumber ke AS tujuan. Tulisan ini membahas penerapan protokol routing BGP dalam jaringan yang memiliki AS yang berbeda supaya dapat melakukan interkoneksi. Penerapannya menggunakan software Packet Tracer 7.0 untuk membuat prototipe jaringan dan mensimulasikannya. Sehingga nantinya dapat diterapkan pada jaringan yang sebenarnya. Berdasarkan pada percobaan yang telah dilakukan, protokol routing BGP dapat menghubungkan dua buah router yang memiliki autonomous system yang berbeda.
\end{abstract}

Keywords - Border Gateway Protocol (BGP), Autonomous Systems (AS), Routing, Router.

\section{Pendahuluan}

Organisasi yang ingin berkembang membutuhkan jaringan komputer dalam pelaksanaan aktivitasnya. Jaringan komputer adalah himpunan "interkoneksi" antara dua komputer autonomous atau lebih yang terhubung dengan media transmisi kabel atau tanpa kabel (wireless) [1]. Perkembangan jaringan komputer yang semakin pesat dewasa ini harus diimbangi dengan mekanisme komunikasi data yang baik. Sebagaimana prinsip dasar dalam komunikasi data bahwa data yang dikirim harus diterima oleh komputer yang dituju dalam waktu yang secepat mungkin [2]. Salah satu aturan dalam komunikasi data untuk menunjang hal itu adalah protokol perutean (routing protocol). Routing protocol merupakan algoritma yang digunakan dalam mengatur proses routing. Routing adalah proses memilih lintasan yang akan ditempuh oleh sebuah paket data pada suatu jaringan komputer [3]. Routing protocol berguna untuk mengatur jalur komunikasi data dalam sebuah jaringan komputer. 
Jaringan komputer yang telah besar terdiri dari dua atau lebih autonomous system. Autonomous system (AS) merupakan jaringan yang independen dan mempunyai menejemen sistem sendiri, memiliki topologi jaringan sendiri, hardware dan software sendiri, dan dapat melakukan interkoneksi dengan jaringan autonomous system lainnya. AS secara sederhana dapat diumpamakan dengan sebuah perusahaan yang memiliki peraturan sendiri yang berbeda dengan perusahaan lain. Memiliki privasi sendiri, struktur manajemen sendiri, strategi bisnis sendiri, kekhasan produk sendiri yang semua itu tidak perlu diketahui oleh perusahaan lain. Namun apabila perusahaan itu menjalin kerjasama dengan perusahaan lain atau ingin menjual produknya pada konsumen, tentunya harus menginformasikan pada dunia di luar perusahaan tersebut. Akan tetapi tidak semua informasi mengenai perusahaan tersebut bisa diakses oleh pihak luar. Hanya informasi tertentu saja yang bisa diakses oleh pihak di luar perusahaan, dan sifatnya sangat terbatas.

AS dalam jaringan komputer skala besar tidak secara otomatis dapat melakukan interkoneksi dengan AS lainnya. Hal tersebut terjadi karena setiap AS memiliki kebijakan routing yang berbeda-beda. Interkoneksi antar AS dalam jaringan akan mengalami masalah apabila tidak dilakukan pengaturan yang tepat dan benar. Permasalahan yang terjadi misalnya tidak bisa mengakses informasi AS lainnya seperti tabel routing untuk pemilihan jalur terbaik, waktu akses yang sangat lama, hilangnya paket data yang dikirimkan, dan ketidak mampuan untuk berdaptasi dengan perubahanperubahan yang terjadi dalam skema jaringan. Untuk itu dibutuhkan pemilihan protokol routing yang tepat sehingga interkoneksi antar AS tidak mengalami noise. Border gateway protocol (BGP) dapat dipilih oleh administrator jaringan untuk melakukan interkoneksi antar AS.

BGP merupakan suatu jalan vektor protokol routing yang menjadikan setiap AS sebagai satu titik di dalam rute jaringan yang akan dilalui oleh paket data untuk tujuan mendapatkan jalur terbaik [4]. BGP tidak digunakan untuk perutean di dalam AS, melainkan untuk perutean antara sistem otonom (AS) yang berbeda. BGP adalah protokol yang kaya yang memiliki banyak cara untuk mempertahankan node serta mengatasi kegagalan jaringan dan perubahan topologi jaringan, sehingga merupakan pilihan yang baik untuk interkoneksi antar sistem otonom [5].

Penelitian mengenai protokol routing BGP ini telah banyak dilakukan. Penelitian [6], disampaikan bahwa BGP sudah cukup berhasil menyediakan routing antar autonomous system yang relatif stabil. BGP berdasarkan hasil penelitian dapat menghubungkan antara dua autonomous system, sehingga komunikasi dapat berjalan dengan lancar. Hal ini menjadikan BGP sebagai alternatif routing antar domain (autonomous system). Penelitian selanjutnya oleh [7] menyatakan bahwa BGP mampu menghubungkan setiap jaringan dari AS, tidak peduli topologi apa yang digunakan oleh skema jaringan ini. BGP dapat beradaptasi dengan perubahan topologi jaringan dari waktu ke waktu. Karakteristik ini membuat interkoneksi BGP tetap terjaga dengan baik.

Penelitian ini bertujuan untuk mengetahui kemampuan protokol routing BGP dalam melakukan interkoneksi jaringan antar autonomous system yang berbeda. Setelah dilakukan konfigurasi bisa mengetahui informasi seperti tabel routing, tebel neighbour, status routing, dan jalur paket data. Tahapan yang dilakukan pada penelitian ini adalah analisis literatur, desain simulasi skema jaringan, pengembangan simulasi skema jaringan dengan melakukan konfigurasi routing BGP, dan pengujian interkoneksi antar AS. Simulasi interkoneksi ini memanfaatkan software Cisco Packet Tracer untuk merancang skema jaringan yang terdiri dari dua buah AS. Hasil simulasi ini dapat diterapkan pada kondisi yang sebenarnya.

\section{LANDASAN TEORI}

\section{A. Autonomous System (AS)}

Autonomous system (AS) adalah satu jaringan atau sekumpulan jaringan yang berada di bawah kontrol satu administrasi. Contoh AS adalah seperangkat komputer di perusahaan atau di perguruan tinggi yang memiliki kontrol administrator yang sama [8].

AS terdiri dari sekelompok router yang membentuk jaringan yang masih berada dalam satu hak administrasi, satu kepemilikan, satu kepentingan, dan dikonfigurasi menggunakan policy yang sama. Biasanya dalam satu AS, router-router di dalamnya dapat bebas berkomunikasi dan memberikan informasi. Umumnya, routing protocol yang digunakan untuk bertukar informasi routing adalah sama pada semua router di dalamnya [9].

AS memiliki nomor identifikasi yang berbeda, nomor ini diatur dan diberikan oleh Internet Assigned Number Authority (IANA). Pemberian nomor AS dimulai dari nomor 1 sampai 65.535. Untuk private $A S$ number berada antara 64.512 sampai dengan 65.535. Dalam penggunaan privat AS number hal yang perlu diperhatikan adalah nomor AS ini tidak boleh sampai keluar jaringan di luar AS. Hal ini akan menimbulkan kekacauan dalam sistem pengalamatan AS [10].

\section{B. Border Gateway Protocol (BGP)}

Border Gateway Protokol (BGP) adalah merupakan salah satu jenis protokol routing yang digunakan untuk koneksi antara autonomous system (AS), dan salah satu jenis protokol routing yang banyak digunakan oleh Internet Service Provider (ISP) besar ataupun untuk perbankan. BGP termasuk dalam kategori protokol routing jenis Exterior Gateway Protocol (EGP). Dengan adanya EGP, router dapat melakukan pertukaran rute dari dan ke luar jaringan lokal AS. BGP mempunyai skalabilitas yang tinggi karena dapat melayani pertukaran routing pada beberapa organisasi besar [9].

BGP bertujuan untuk memilih jalur-jalur interdomain dan jalur antara AS number di dalam internet. Fungsi utama dari BGP adalah untuk mempertukarkan informasi jaringan antar suatu BGP router dengan BGP router yang lain. Dalam 
informasi ini terdapat juga informasi jumlah AS yang berada dalam jalur penyampaian informasi tersebut. Dengan adanya informasi ini, dapat dibentuk grafik dari AS path yang saling terkoneksi sehingga dapat menghindari terjadinya routing loop. Selain fungsi di atas, BGP juga digunakan untuk menerapkan policy routing di tingkat interdomain [11].

\section{External Border Gateway Protocol (EBGP)}

Pada EBGP ketika sebuah router BGP menerima informasi routing baru dari router yang terhubung dari AS lain, dia akan mendistribusikan informasi tersebut ke semua router lain yang terhubung. Di sini tidak dibutuhkan sebuah router harus terhubung ke router BGP lainnya dan cukup untuk dihubungkan ke setidaknya satu router BGP saja, karena semua informasi router tetangga akan konsisten setelah beberapa hop otomatis karena informasinya disiarkan [12].

Fungsi utama EBGP adalah membuat komunikasi antara kedua gateway host router yaitu antara dua autonomous system yang berbeda. BGP dikonfigurasi pada kedua tepi router gateway dari dua autonomous system yang berbeda. Router tepi dari dua autonomous systems berkomunikasi melalui EBGP. BGP saat digunakan sebagai EBGP, memiliki keuntungan besar karena memiliki jarak administratif yang sangat efisien yaitu 20 [8].

Gbr. 1 di bawah ini meruapakan model skema jaringan EBGP. Ada dua buah router tepi yang memiliki AS berbeda, yaitu AS 1 untuk R1 dan AS2 untuk R2. Kedua buah router diatur dengan protokol routing BGP. Jenis interkoneksi antara dua buah router tersebut pada saat dihubugnkan adalah EBGP.

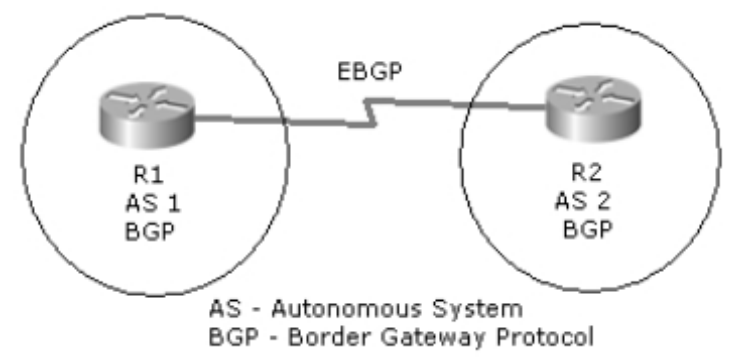

Gbr. 1 BGP bekerja sebagai External BGP antara tepi dua router dari autonomous system yang berbeda [8]

\section{Internal Border Gateway Protocol (IBGP)}

IBGP digunakan saat paket BGP dikirim antara router dalam AS yang sama. Dalam mode ini, ketika sebuah router BGP menerima informasi routing dari salah satu tetangga IBGP-nya, dia tidak menyiarkan informasi tersebut ke rekan BGP lain yang terhubung. Setiap router BGP harus memiliki koneksi IBGP ke semua router BGP lainnya di AS yang sama untuk mencapai interkoneksi di seluruh jaringan [12].

Internal BGP digunakan jika dalam satu Autonomous System (AS) atau jaringan internal AS yang sama ingin menggunakan konfigurasi BGP [13]. Tapi ada banyak masalah yang dihadapi BGP saat dijadikan sebagai IBGP [8].
Untuk merutekan informasi dalam autonomous system yang sama ada banyak Interior Gateway Protocols (IGP) misalnya Routing Information protocol (RIP), RIP version 2, Enhanced Interior Gateway Protocol (EIGRP), dan Open Shortest Path First (OSPF). Semua protokol yang disebutkan tadi melakukan pekerjaan yang sama dengan IBGP [8].

Gbr. 2 di bawah ini menunjukkan model skema jaringan yang dikategorikan sebagai IBGP. Terdapat empat buah router yang saling terhubung dan merupakan satu AS yang sama. Protokol routing yang dapat diterapkan pada Gambar 2 antara lain RIP, RIPv2, IGRP, EIGRP, OSPF, dan BGP yang berperan sebagai IBGP.

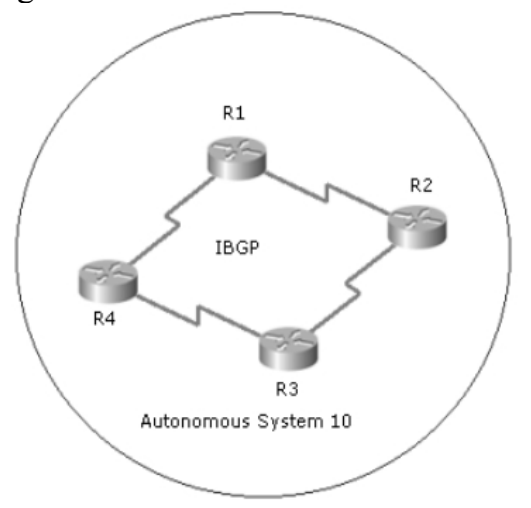

Gbr. 2 Jaringan Internal Border Gateway Protocol [8]

\section{E. AS-Path}

Setiap sebuah rute disebarkan melalui BGP, akan diberi "perangko" dengan sebuah nomor AS (AS number) dari router yang menyelenggarakannya. Rute ini bergerak dari satu autonomous system (AS) ke autonomous system (AS) lain sehinggap membentuk sebuah alur atau path yang dinamakan AS-Path. Setiap rute akan bermula dari "null AS-Path", direpresentasikan dengan ekspresi regular “^\$” [14].

AS-path memuat rangkaian segmen jalur autonomus system. Nilai AS number akan ditambahkan ke dalam atribut $A S \_$path pada saat rute akan dikirim ke AS number yang lainnya. $A S$ path mencantumkan semua AS yang perlu dilalui untuk mencapai lokasi tujuan. Tujuan utama $A S$ path adalah untuk menghindari loop. Tanpa $A S$ path BGP akan bekerjai sangat mirip dengan Routing Information Protocol (RIP). Karena baik RIP dan BGP adalah merupakan distance vector routing protocols, dimana router pada dasarnya mengirimkan salinan tabel routing-nya sendiri ke tetangganya, dan tetangga kemudian menggunakan rute tersebut jika mereka lebih baik daripada rute yang sebelumnya.

\section{F. Atribut BGP}

Salah satu ciri khas dan juga merupakan kekuatan dari protokol routing BGP ada pada atribut-atribut pendukungnya. Atribut-atribut ini yang nantinya digunakan sebagai parameter untuk menentukan jalur terbaik untuk menuju ke suatu situs. Atribut ini juga dapat mengatur keluar masuknya routing update dari router-router BGP tetangga. Dengan mengatur 
atribut ini, dapat dengan bebas mengatur bagaimana karakteristik dan sifat dari sesi BGP tersebut [14].

Terdapat sebelas jenis atribut dalam BGP. Setiap atribut memilik ciri khas dan fungsi yang berbeda untuk melakukan manajemen dalam protokol routing BGP. Atribut BGP tersebut yaitu Origin, AS-Path, Next hop, Multiple Exit Discriminator (MED), Local Preference, Atomic Aggregate, Aggregrator, Community, Originator ID, Cluster List, dan Weight.

\section{G. BGP Messages}

Terdapat empat jenis BGP messages, yaitu open messages, keep-alive, update messages, dan notification messages [12]. Berikut merupakan penjabaran dari BGP message [15].

1) Open Message: Open messages membuka sesi komunikasi antara router BGP dan merupakan pesan pertama yang dikirim oleh masing-masing router setelah sambungan protokol transport ditetapkan. Open messages dikonfirmasikan dengan menggunakan pesan Keep-Alive yang dikirim oleh perangkat router lainnya dan harus dikonfirmasi sebelum pembaruan, pemberitahuan, dan keep-alives dapat ditukar.

2) Update Message: Update message digunakan untuk memberikan update routing ke sistem BGP lainnya, yang memungkinkan router untuk membangun pandangan yang konsisten mengenai topologi jaringan. Pembaruan dikirim menggunakan TCP untuk memastikan pengiriman yang andal. Update messages dapat menarik satu atau beberapa rute yang tidak layak dari tabel routing dan secara bersamaan dapat memberitahukan sebuah rute baru sambil menarik kembali rute yang lain.

3) Notification Message: Notification message dikirim saat kondisi kesalahan terdeteksi. Pemberitahuan digunakan untuk menutup sesi aktif dan menginformasikan router yang terhubung mengapa sesi ditutup. Pesan ini berisikan field-field yang berisi jenis error apa yang telah terjadi, sehingga sangat memudahkan penggunaannya untuk melakukan troubleshoting.

4) Keep-Alive Message: Keep-Alive message memberitahukan sesama router BGP agar perangkat selalu aktif. Keep-Alive message dikirim cukup sering untuk menjaga agar sesi tidak kedaluwarsa. Sesuai spesifikasi, timer penahan disetel ulang setelah menerima pesan tetap-hidup atau pembaruan. Paket ini berukuran 19 byte dan tidak berisikan data sama sekali.

\section{H. Karakteristik BGP}

Beberapa karakteristik protokol routing BGP adalah sebagai berikut [14]:

1. BGP adalah Path Vector routing protocol yang dalam proses menentukan rute-rute terbaiknya selalu mengacu kepada path yang terbaik dan terpilih yang didapatnya dari router BGP yang lainnya.
2. Tabel routing akan dikirim secara penuh pada awal dari sesi BGP, update selanjutnya hanya bersifat incremental atau menambahi dan mengurangi routing yang sudah ada.

3. Router BGP membangun dan menjaga koneksi antar peer menggunakan port TCP nomor 179.

4. Koneksi antar peer dijaga dengan menggunakan sinyal keep-alive secara periodik.

5. Kegagalan menemukan sinyal keep-alive, routing update, atau sinyal-sinyal notifikasi lainnya pada sebuah router BGP dapat memicu perubahan status BGP peer dengan router lain, sehingga mungkin saja akan memicu updateupdate baru ke router yang lain.

6. Metrik yang digunakan BGP untuk menentukan rute terbaik sangat kompleks dan dapat dimodifikasi dengan sangat fleksibel. Ini merupakan sumber kekuatan BGP yang sebenarnya. Metrik - metrik tersebut sering disebut dengan istilah Atribut.

7. Penggunaan sistem pengalamatan hirarki dan kemampuannya untuk melakukan manipulasi aliran trafik membuat protokol routing BGP sangat skalabel untuk perkembangan jaringan di masa mendatang.

8. BGP memiliki routing table sendiri yng biasanya memuat informasi prefix-prefix routing yang diterimanya dari router BGP lain. Prefix-prefix ini juga disertai dengan informasi atributnya yang dicantumkan secara spesifik di dalamnya.

9. BGP memungkinkan memanipulasi trafik menggunakan atribut-atributnya yang cukup banyak. Atribut ini memiliki tingkat prioritas untuk dijadikan sebagai acuan.

\section{Tahapan Kerja BGP}

Tahapan kerja protokol routing BGP dijelaskan sebagai berikut [16].

1) Routes received from peers: Pada tahap ini, router BGP menerima informasi routing dari router pasangannya baik internal maupun eksternal. Tergantung dari kebijakan yang diterapkan pada router BGP, beberapa atau semua informasi yang didapat akan dimasukkan ke dalam tabel routing.

2) Input policy engine: Pada tahap ini router BGP akan melakukan proses filtering terhadap informasi yang didapat pada tahap sebelumnya. Informasi yang telah diseleksi selanjutnya akan dibawa ke tahap berikutnya untuk dilakukan proses pengambilan keputusan jalur terbaik.

3) The decision process: Pada tahap ini akan dilakukan proses pengambilan keputusan terhadap jalur-jalur yang ada. Pengambilan keputusan ini diambil berdasarkan informasi dari proses sebelumnya. Proses ini bertujuan untuk mendapatkan lebih dari satu rute untuk mencapai tujuan jaringan tertentu.

4) Routes used by user: Setelah mendapatkan rute-rute yang dapat ditempuh untuk sampai ke jaringan tujuan, pada tahap ini informasi itu akan disusun untuk mendapatkan jalur terbaik. Selanjutnya informasi yang telah didapat akan dimasukkan ke dalam tabel routing. Informasi hasil seleksi ini 
nantinya juga akan diberikan ke BGP pasangannya setelah melalui tahap berikutnya.

5) Output policy engine: Pada tahap ini informasi routing yang telah didapatkan akan diteruskan ke BGP pasangannya. Proses seleksi yang dilakukan pada tahap ini adalah membedakan antara BGP pasangan yang internal dan yang eksternal. Untuk jalur routing yang berasal dari internal AS tidak boleh dilanjutkan ke pasangan BGP yang internal juga. Ini untuk mencegah routing loop terjadi.

6) Routes advertised to peers: Pada tahap akhir ini, informasi routing yang telah diproses akan diteruskan ke semua BGP pasangannya. Baik eksternal maupun internal AS [17], seperti terlihat pada Gbr. 3 berikut ini.

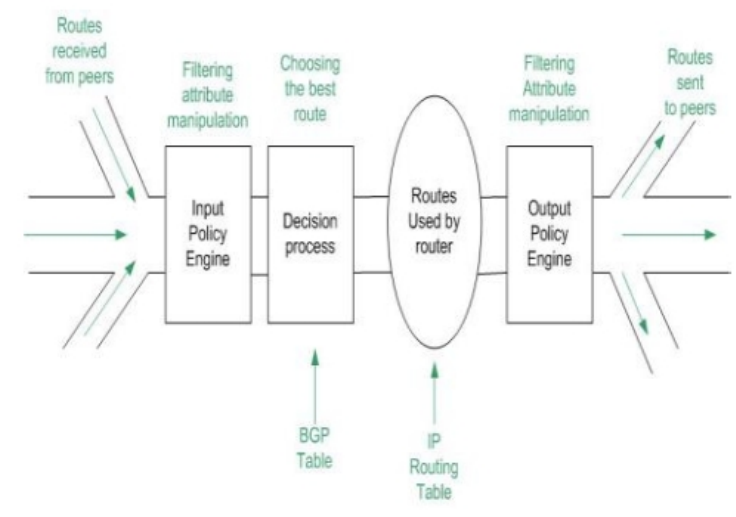

Gbr. 3 Diagram tahapan proses kerja BGP

\section{J. Teknik Pemilihan Rute BGP}

Proses pemilihan rute terbaik untuk suatu prefix tujuan melibatkan kriteria pemilihan yang sering disebut dengan best path selection algorithm yang akan dijelaskan berikut ini [18]:

1. Memilih rute dengan nilai $L O C A L \_P R E F$ yang terbesar.

Atribut ini digunakan untuk memilih rute yang lebih diprioritaskan dibanding rute lain untuk prefix tujuan yang sama. Rute yang memiliki nilai $L O C A L_{-} P R E F$ yang lebih besar akan lebih diprioritaskan.

2. Memilih rute dengan $A S P A T H$ terpendek. Ketika informasi routing dipropagasikan dalam jaringan, ASN akan ditambahkan dalam AS_PATH. Dengan memilih $A S \_P A T H$ terpendek, BGP mengasumsikan semakin pendek $A S P A T H$ maka semakin kecil delay yang akan diperoleh. Tentunya hal ini tidak sepenuhnya benar dalam kenyataannya di internet.

3. Memilih rute dengan nilai ORIGIN yang terkecil. Atribut ini mengindentifikasikan bagaimana suatu originating AS mengetahui tentang suatu rute. Nilai ORIGIN ini dapat berupa IGP, EGP, maupun INCOMPLETE.

4. Memilih rute dengan nilai $M E D$ terkecil. Rute tanpa atribut $M E D$ dianggap memiliki $M E D$ terendah. $M E D$ ini digunakan untuk memilih egress point dalam domain lokal. Aplikasi $M E D$ yang paling sering digunakan adalah cold potato routing yang bertujuan untuk membawa trafik selama mungkin berada dalam domain lokal sebelum diteruskan ke domain tetangga.

5. Memilih rute eBGP dibandingkan rute iBGP. Hal ini digunakan agar paket dapat segera mungkin meninggalkan domain (hot potato routing).

6. Memilih rute yang memiliki IGP cost paling kecil menuju egress point. Hal ini bertujuan juga agar paket dapat segera mungkin meninggalkan domain (hot potato routing). Hal ini dicapai dengan cara mengarahkan trafik ke border router terdekat berdasarkan nilai IGP cost.

7. Pemilihan rute terbaik berdasarkan implementasi vendor secara spesifik jika masih terdapat rute yang memiliki paling sedikit dua alternatif hingga langkah ini. Contohnya memilih rute yang memiliki alamat IP paling kecil, atau memilih rute yang berumur lebih lama.

Aturan-aturan di atas, kecuali nomor satu, disebut dengan aturan tie-breaking dari proses keputusan dalam BGP. Algoritma tie-breaking ini dimulai dengan menganggap semua rute menuju ke tujuan adalah sama dan sebanding, kemudian algoritma ini memilih rute-rute yang akan dihapus dari pertimbangan.

\section{METODE PENELITIAN}

Pada tulisan ini metode penelitian yang digunakan adalah sebagai berikut :

1. Analisis. Pada tahapan ini dilakukan analisis literatur yang relevan. Literatur bersumber dari buku, jurnal ilmiah, dan penelitian yang membahas mengenai Border Gateway Protocol (BGP).

2. Desain. Tahapan ini berisikan bentuk prototipe topologi jaringan yang dikembangkan. Meliputi skenario jaringan secara fisik dan juga logika. Perancangan prototipe jaringan memanfaatkan software simulasi jaringan komputer Cisco Packet Tracer.

3. Pengembangan. Tahapan ini dilakukan untuk mengkonfigurasi prototipe topologi jaringan. Konfigurasi dilakukan pada setiap device yang ada di dalam prototipe jaringan, antara lain adalah PC, server, dan router. Konfigurasi routing protocol BGP dilakukan di router dengan mengetikkan kode program pada jendela CLI router tersebut. Pengaturan router dilakukan untuk menghasilkan jalur terbaik untuk melewatkan paket data dalam jaringan.

4. Pengujian. Setelah prototipe jaringan selesai dikembangkan, setiap device dilakukan pengujian konektivitasnya. Kemudian juga dilakukan pemeriksaan routing BGP. 


\section{HASIL DAN PEMBAHASAN}

\section{K. Skema Jaringan}

Skema jaringan pada simulasi interkoneksi antara autonomous system (AS) menggunakan border gateway protocol (BGP) seperti Gbr. 4 di bawah ini.

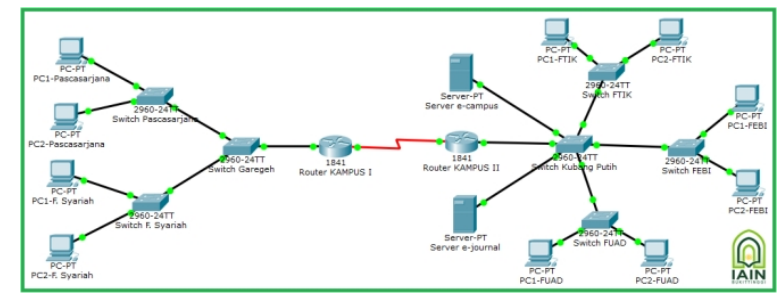

Gbr. 4 Skema jaringan untuk penelitian

Skema jaringan yang terdapat pada Gbr. 4 di atas memiliki dua buah router. Setiap router memiliki alamat IP address masing-masing pada port yang diaktifkan. Server e-campus dan server e-journal merupakan tujuan yang akan diakses oleh setiap client yang ada. Protokol routing yang digunakan pada kedua buah router adalah BGP. Tabel 1 berikut ini adalah pengaturan IP address pada masing-masing router.

TABEL I

KONFIGURASI ALAMAT ROUTER

\begin{tabular}{|c|c|c|}
\hline Router & $\begin{array}{l}\text { Port : IP Address / } \\
\text { Prefix }\end{array}$ & $\begin{array}{l}\text { Clock } \\
\text { Rate }\end{array}$ \\
\hline Kampus I & $\begin{array}{l}\mathrm{Fa} 0 / 0 \quad: 192.172 .12 .1 \\
/ 24 \\
\mathrm{Se} 0 / 0 / 0: 178.32 .4 .1 / 24 \\
\text { Loopback } 0: 8.4 .2 .1 / 24\end{array}$ & $\begin{array}{l}- \\
- \\
-\end{array}$ \\
\hline $\begin{array}{l}\text { Kampus } \\
\text { II }\end{array}$ & $\begin{array}{l}\mathrm{Se} 0 / 0 / 0: 178.32 .4 .2 / 24 \\
\mathrm{Fa} 0 / 0 \quad: 150.64 .26 .1 / 24 \\
\text { Loopback } 0: 17.15 .13 .1 \\
/ 24\end{array}$ & $\begin{array}{l}2000000 \\
- \\
-\end{array}$ \\
\hline
\end{tabular}

Merujuk pada tabel $1 \mathrm{di}$ atas, terdapat istilah IP loopback. Loopback IP address adalah bersifat virtual (semu) yang bisa digunakan untuk identitas router dalam jaringan. Artinya interface loopback merupakan interface logika dan bukan fisik sehingga interface ini secara nyata tidak ada. Loopback tidak memiliki kabel fisik yang terhubung ke router atau switch. Loopback merupakan interface yang tidak pernah berada dalam posisi "down", sedangkan interface fisik dapat mati atau mengalami down ketika terjadi kesalahan pengkabelan. Sehingga IP Address pada interface loopback ini sangat cocok untuk dijadikan sebagai router ID. IP loopback diatur dengan IP yang tertinggi yaitu dengan subnet mask 255.255.255.255.

Pengaturan interface loopback pada kedua router adalah seperti berikut ini.

1. Pengaturan IP loopback pada router Kampus I :

Router $>$ enable

Router\#configure terminal
Router(config)\#hostname Router-KAMPUS_I

Router-KAMPUS_I(config)\#interface loopback 0

Router-KAMPUS_I(config-if)\#ip address 8.4.2.1

255.255.255.0

Router-KAMPUS I(config-if)\#no shutdown

Router-KAMPUS_I(config-if)\#exit

2. Pengaturan IP loopback pada router Kampus II :

Router $>$ enable

Router\#configure terminal

Router(config)\#hostname Router-KAMPUS_II

Router-KAMPUS I(config)\#interface loopback 0

Router-KAMPUS_I(config-if)\#ip address 17.15.13.1 255.255.255.0

Router-KAMPUS_I(config-if)\#no shutdown

Router-KAMPUS_I(config-if)\#exit

Konfigurasi IP address untuk komputer client dapat dilihat pada tabel 2 di bawah ini.

TABEL II

KONFIGURASI ALAMAT PC

\begin{tabular}{|c|c|c|}
\hline Perangkat & $\begin{array}{l}\text { IP Address } \\
\text { /Prefix }\end{array}$ & $\begin{array}{c}\text { Default } \\
\text { Gateway }\end{array}$ \\
\hline Server e-campus & $150.64 .26 .2 / 24$ & 150.64 .26 .1 \\
\hline Server e-journal & $150.64 .26 .3 / 24$ & 150.64 .26 .1 \\
\hline $\begin{array}{l}\text { PC-1 } \\
\text { Pascasarjana }\end{array}$ & $\begin{array}{l}192.172 .12 .2 \\
/ 24\end{array}$ & 192.172 .12 .1 \\
\hline $\begin{array}{l}\text { PC-2 } \\
\text { Pascasarjana }\end{array}$ & $\begin{array}{l}192.172 .12 .3 \\
/ 24\end{array}$ & 192.172 .12 .1 \\
\hline PC-1 F. Syariah & $\begin{array}{l}192.172 .12 .4 \\
/ 24\end{array}$ & 192.172 .12 .1 \\
\hline PC-2 F. Syariah & $\begin{array}{l}192.172 .12 .5 \\
/ 24\end{array}$ & 192.172.12.1 \\
\hline PC-1 FEBI & $150.64 .26 .7 / 24$ & 150.64.26.1 \\
\hline PC-2 FEBI & $150.64 .26 .6 / 24$ & 150.64 .26 .1 \\
\hline PC-1 FUAD & $150.64 .26 .8 / 24$ & 150.64 .26 .1 \\
\hline PC-2 FUAD & $150.64 .26 .9 / 24$ & 150.64 .26 .1 \\
\hline PC-1 FTIK & $150.64 .26 .5 / 24$ & 150.64 .26 .1 \\
\hline PC-2 FTIK & $150.64 .26 .4 / 24$ & 150.64 .26 .1 \\
\hline
\end{tabular}

Router dan pc yang ada di dalam topologi diatur alamatnya berdasarkan pada tabel konfigurasi alamat di atas. Selanjutnya dilakukan tes koneksivitas setiap router dan pc. Hasil tes ini didapatkan bahwa pc yang berada (terhubung langsung) pada satu router yang sama akan dapat saling berkomunikasi. Komunikasi antara satu pc dengan pc lainnya yang berada pada router berbeda belum bisa dilakukan. Hal ini karena diperlukan pengaturan routing di masing-masing router.

\section{Konfigurasi Protokol Routing BGP}

Pengaturan routing pada tahapan ini menggunakan protokol routing BGP. Gambar 5 menunjukkan bahwa pengaturan BGP untuk menghubungkan kedua buah router adalah 
menggunakan EBGP. Terlihat dari Gbr. 5 bahwa AS Number router Kampus I adalah 100, sedangkan AS Number router Kampus II yaitu 200. Router yang ada pada topologi dikonfigurasi dengan menuliskan script pada jendela IOS Command Line Interface milik masing-masing router tersebut.

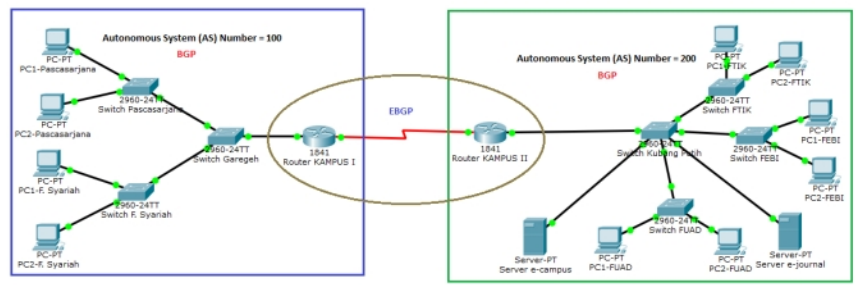

Gbr. 5 Pembagian autonomous system number pada skema jaringan penelitian

Pengaturan routing BGP pada setiap router adalah sebagai berikut :

1. Pengaturan routing BGP pada router Kampus I :

Router-KAMPUS I\#configure terminal

Router-KAMPUS_I(config)\#router bgp 100

Router-KAMPUS_I(config-router)\#neighbor 178.32.4.2

remote-as 200

Router-KAMPUS_I(config-router)\#network 8.4.2.0 mask 255.255.255.0

Router-KAMPUS_I(config-router)\#redistribute connected Router-KAMPUS_I(config-router)\#exit

2. Pengaturan routing BGP pada router Kampus II :

Router-KAMPUS_IIHconfigure terminal

Router-KAMPUS_II(config)\#router bgp 200

Router-KAMPUS_II(config-router)\#neighbor 178.32.4.1

remote-as 100

Router-KAMPUS_II(config-router)\#network $\quad$ 17.15.13.0 mask 255.255.255.0

Router-KAMPUS_II(config-router)\#redistribute connected Router-KAMPUS_II(config-router)\#exit

\section{Analisis Penerapan Protokol Routing BGP}

Setelah semua router diatur routing-nya, maka semua pc dapat saling terhubung satu dengan yang lainnya. Berikutnya ada beberapa hal yang bisa kita analisa terhadap pengaturan routing yang telah dilakukan. Diantara yang dapat kita lihat adalah sebagai berikut.

1) Tabel Routing: Pada tahapan ini dilakukan pemeriksaan tabel routing yang dihasilkan oleh protokol routing BGP. Perintah yang digunakan adalah show ip route bgp. Berikut ini adalah Gbr. 6 yang menampilkan tabel routing di router Kampus I.

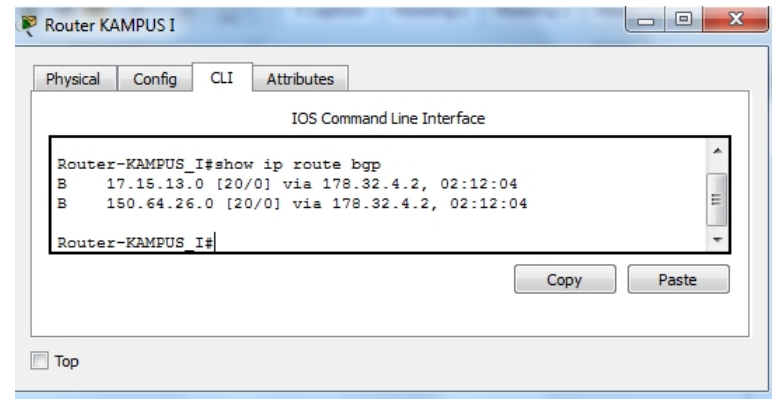

Gbr. 6 Tabel routing BGP di router Kampus I

2) Tabel Neighbor: Tabel neighbor berisi semua router neighbor. Ketika router menemukan dan menjalin hubungan adjacency (ketetanggaan) dengan neighbor baru, maka router akan menyimpan address router neighbor beserta interface yang dapat menghubungkan dengan neighbor tersebut sebagai satu entri dalam tabel neighbor. Berikut ini adalah tabel neighbor protokol BGP pada Kampus I yang disajikan pada Gbr. 7.

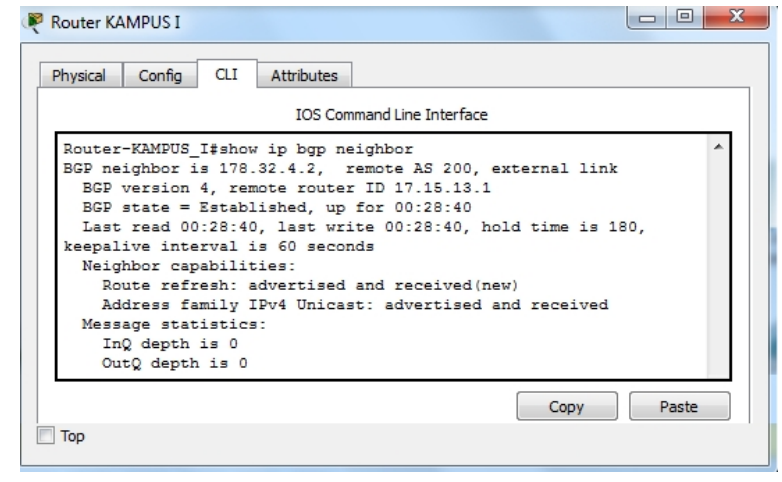

Gbr. 7 Tabel neighbor di router Kampus I

3) Pengaturan IP protocol: Untuk melihat pengaturan IP protokol dengan menggunakan perintah show ip protocol. Gbr. 8 di bawah ini merupakan informasi IP protokol pada router Kampus I. 


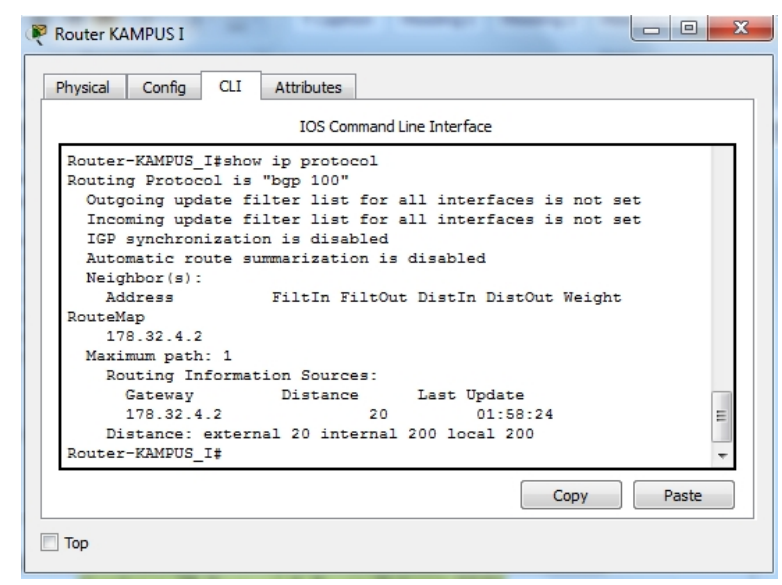

Gbr. 8 IP protocol di router Kampus I

4) Pengaturan BGP: Perintah show ip bgp berguna untuk melihat pengaturan BGP di router yang dipilih. Perintah ini digunakan untuk menampilkan isi tabel routing BGP. Outputnya dapat disaring untuk menampilkan entri spesifik dari prefix, prefix length, dan prefiks yang disuntikkan melalui prefix list, peta rute, atau advertise kondisional. Hasilnya dapat dilihat pada Gbr. 9 berikut.

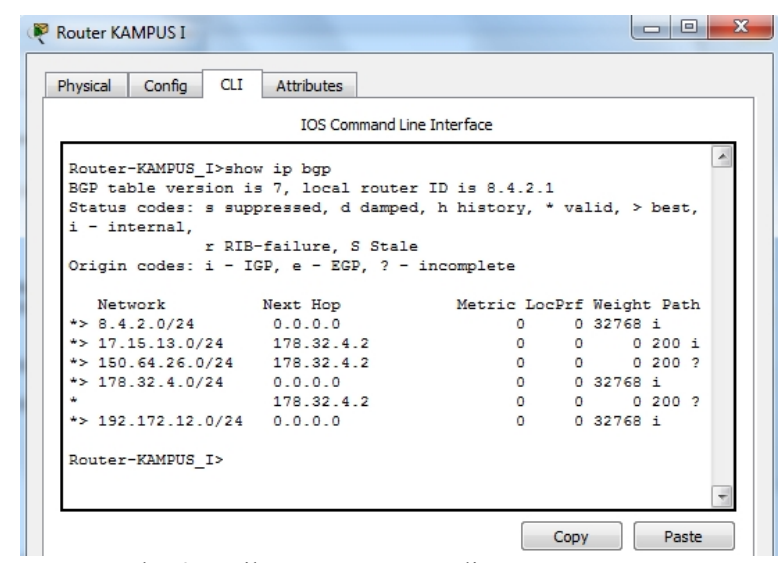

Gbr. 9 Hasil pengaturan BGP di router Kampus I

5) Jalur Paket Data: Perintah tracert digunakan untuk mencari jalur yang akan dilalui oleh paket data, tracert ini menggunakan protokol ICMP (Internet Control Messaging Protocol). Cara kerjanya adalah dengan mengirimkan ICMP messages yang disebut IP datagrams dengan parameter waktu yang disebut timeout. Berikut ini adalah hasil dari penelusuran jalur paket data. Gbr. 10 berikut adalah hasil pengujian tracerout dari router Kampus I ke server e-campus (150.64.26.2) dan server e-journal (150.64.26.3).

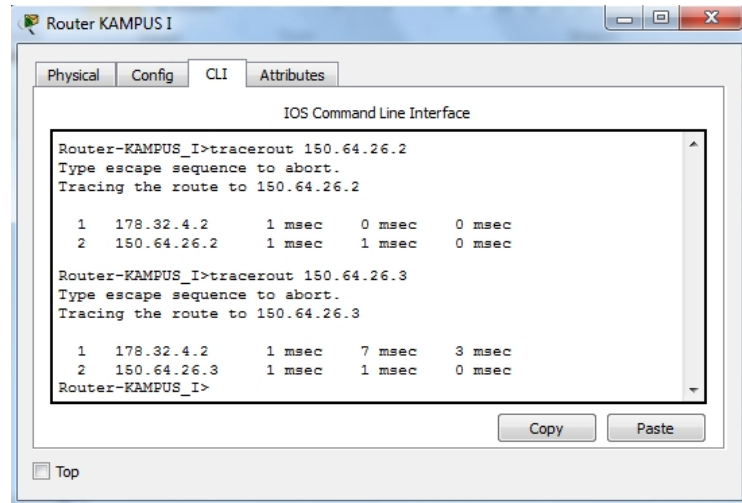

Gbr. 10 Hasil tracerout dari router Kampus I ke server e- campus dan ejournal

6) Status routing BGP: Melihat semua status koneksi routing BGP dilakukan dengan perintah show ip bgp summary. Perintah ini digunakan untuk menampilkan informasi $B G P$ path, prefix, dan informasi atribut untuk semua koneksi ke router tetangga. Gbr. 11 memberikan informasi status routing BGP Router Kampus I seperti pada di bawah ini.

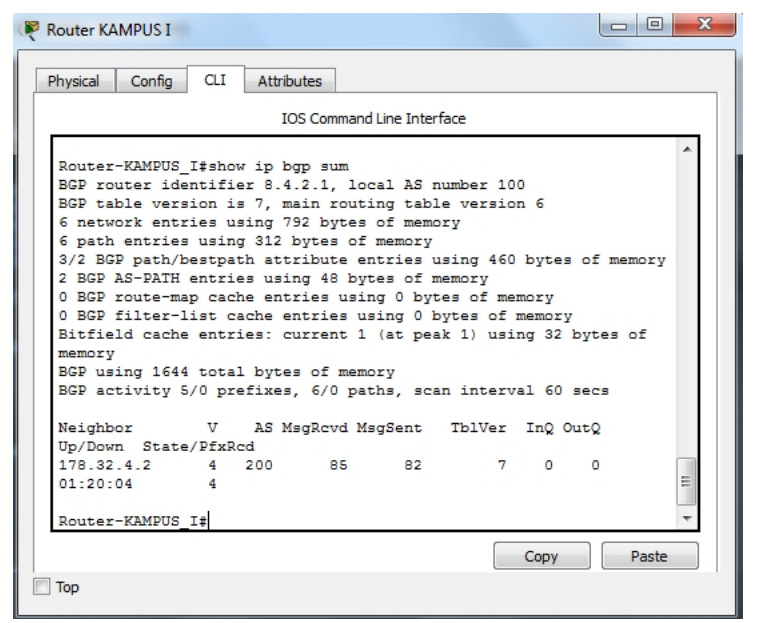

Gbr. 11 Status router Kampus I

\section{PENUTUP}

\section{A. Kesimpulan}

Berdasarkan pada simulasi interkoneksi yang telah dilakukan, BGP berperan sebagai protokol routing antara autonomous system yang berbeda. Sehingga memiliki kemampuan melakukan pertukaran rute dari dan ke luar jaringan lokal sebuah autonomous system number. BGP juga merupakan routing protocol yang sangat reliable kerjanya. Hal ini dikarenakan BGP menggunakan protokol TCP untuk berkomunikasi dengan tetangganya dalam melakukan pertukaran informasi. TCP merupakan protokol yang menganut sistem reliable service, dimana setiap sesi komunikasi yang dibangun berdasarkan protokol ini harus dipastikan sampai tidaknya. BGP menggunakan alamat IP dan AS Number untuk meneruskan paket-paket data dan 
memperbarui tabel routing. Atribut yang dimiliki oleh BGP dapat digunakan sebagai parameter untuk menentukan jalur terbaik untuk menuju ke suatu tujuan. Atribut ini juga dapat mengatur keluar masuknya routing update dari router BGP tetangga. Dengan mengatur atribut ini, adminisitrator jaringan dapat dengan bebas mengatur bagaimana karakteristik dan sifat dari sesi BGP tersebut.

\section{B. Saran}

Untuk penelitian berikut, bisa mengembangkan skema jaringan yang lebih komplek dengan berbagai jenis topologi jaringan.

\section{REFERENS}

[1] M. Syafrizal, Pengantar Jaringan Komputer. Yogyakarta : Andi Offset, 2005.

[2] F. Pratama, and L. Marlinda, "Perancangan Jaringan Komputer Menggunakan Aplikasi VHP Online Reporting System," Jurnal Teknik Komputer AMIK BSI, vol. 1, no. 1, pp. 106-113, 2015.

[3] H. A. Musril, "Analisis Unjuk Kerja RIPv2 dan EIGRP dalam Dynamic Routing Protocol," Jurnal Elektro Telekomunikasi Terapan (JETT), vol. 2, no. 2, pp. 116-124, 2015.

[4] G. Barovih, "Simulasi Routing BGP Pada PC Router berbasic Opensource," Jurnal Teknologi dan Informatika (TEKNOMATIKA), vol. 5, no. 1, pp. 82-91, 2015.

[5] Vishes, M. Srinath, Suhas, S. Murthy, and A. Tejas, "Border Gateway Protocol (BGP): A Boon to Internet Application and ISPs," International Journal of Advanced Research in Computer and Communication Engineering (IJARCCE), vol. 5, no. 11, pp. 46-51, 2016

[6] V. Sharmila, and M. Kalimuthu, "Interdomain Routing Between Autonomous Systems Using Border Gateway Protocol," International Journal of Advanced Trends in Engineering and Technology (IJARTET), vol. 2, special issue. 1, Maret 2015.

[7] S. Krijestorac, M. Beck, and J. Bagby, "Border Gateway Protocols," in Proceedings of The IAJC-ASEE International Conference, paper 106 , 2011

[8] N. H. Bhagat, "Border Gateway Protocol - A Best Performance Protocol when used for External Routing than Internal Routing," International Journal of Applied Information Systems (IJAIS), vol.3, no. 2, pp. 29-32, 2012

[9] C. K. Sondy, Rancang Bangun Jaringan Untuk SMK/NAK Kelas XI Semester 2. Jakarta: Kementrian Pendidikan \& Kebudayaan, 2014.

[10] Krisnawijaya, N. K. Ngakan, and R. A. Paramartha, "Penerapan Jaringan Multihoming Pada Jaringan Komputer Fakultas Hukum," Jurnal Ilmu Komputer, vol. 9, no. 1, pp. 23-31, 2016.

[11] E. Wismiana, "Manajemen Alamat IPv4 Pada Sistem IP Telephony Dalam Suatu SOHO," Jurnal Teknologi UNPAK, vol. 1, no. 21, pp. 62-73, 2012.

[12] M. Emami, "Performance Comparison of BGP in Multi-AS Network with OPNET Simulator," Advances in Computer Science and its Applications (ACSA), vol. 2, no. 2, pp. 365-368, 2012.

[13] I. G. P. Yasa W, A. Fatchur R, and Y. Christyono, "Desain Dan Simulasi Internal Border Gateway Protocol (IBGP) Menggunakan Graphical Network Simulator (Studi Kasus Pada Jaringan Universitas Diponegoro)," TRANSMISI: Jurnal Ilmiah Teknik Elektro, vol. 16, no. 1, pp. 20-25, 2014.

[14] A. Kodar, “Analisa Dan Uji Kinerja PC Router Yang Menjalankan Protokol Routing Border Gateway Protocol (BGP) Menggunakan Zebra/Quagga," Prosiding Seminar Nasional Pengaplikasian Telematika Sinaptika, pp. 162-167, 2010.

[15] P. R. Gundalwar, and V. N. Chavan, "Border Gateway Protocol (BGP): A Simulation Based Overview," International Journal of Application or Innovation in Engineering \& Management (IJAIEM), vol. 2, no. 3, pp. $275-282,2013$
[16] Chiarella, CCNA (Cisco Certified Network Associate) Self Study Guide (Exam \#640-801). United States: Delmar Learning, 2006.

[17] M. Mc. Gregor, CCNP Cisco Networking Academy Program: Semester Five Companion Guide Advanced Routing. Indianapolis: Cisco Press, 2001.

[18] A. S. Bramantyo, Optimasi Interdomain Routing Dengan BGP Pada Stub-Multihomed Autonomous System. Bandung: Skripsi Mahasiswa Institut Teknologi Bandung, 2007. 